\title{
HBEGF wt Allele
}

National Cancer Institute

\section{Source}

National Cancer Institute. HBEGF wt Allele. NCI Thesaurus. Code C51420.

Human HBEGF wild-type allele is located within $5 q 23$ and is approximately $14 \mathrm{~kb}$ in length.

This allele, which encodes heparin-binding EGF-like growth factor protein, is involved in mitogenesis and cellular proliferation. 